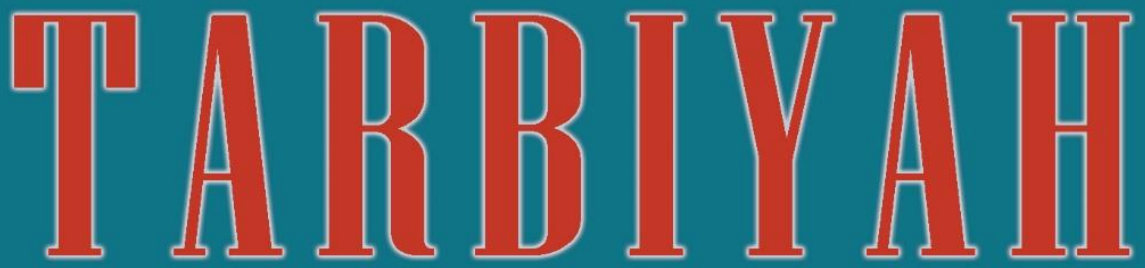

KONTRIBUSI LINGKUNGAN BELAJAR DAN PROSES PEMBELAJARAN TERHADAP PRESTASI BELAJAR SISWA DI SEKOLAH

ANALISIS TERHADAP KEBIJAKAN PEMERINTAHTENTANG PENDIDIKAN AGAMA DAN KEAGAMAAN (MELACAK DAMPAKNYA TERHADAP PENDIDIKAN ISLAM)

MOTIVASI KERJA DAN LINGKUNGAN BELAJAR DALAM UPAYA PENINGKATAN PROSES PEMBELAJARAN

PENGARUH KEGIATAN HANDICRAFT TERHADAP MOTORIK HALUS ANAKTK KELOMPOK B DITK KARUNIA KECAMATANTUNTUNGAN

REKONDISI SILABUS MATAKULIAH PENDIDIKAN AGAMA ISLAM PADA PRODI DESAIN GRAFIS KONSENTRASI MULTIMEDIA POLITEKNIK NEGERI MEDIA KREATIF PSDD MEDAN

HERMENEUTIKA DAN KHAZANAH KEILMUAN ISLAM

PENGARUH PERSEPSI TENTANG SUPERVISI KEPALA SEKOLAH, BUDAYA ORGANISASI DAN MOTIVASI BERPRESTASI TERHADAP KINERJA GURU MTS SWASTA SUB RAYON 44 KEBUPATEN DELI SERDANG

PENINGKATAN PRESTASI BELAJAR MAHASISWA MELALUI PENDEKATAN SAVI PADA MATA KULIAH CURRICULUM AND MATERIAL DEVELOPMENT

PENGEMBANGAN BAHAN AJAR KOMIK UNTUK MENINGKATKAN MINAT BACA PPKn SISWA MIN RAMBA PADANG KABUPATEN TAPANULI SELATAN

PENGAWAS SEKOLAH PENENTU KUALITAS PENDIDIKAN

Diterbitkan oleh Fakultas IImu Tarbiyah dan Keguruan UIN Sumatera Utara Bekerjasama dengan HS-PAI Sumatera Utara 


\title{
JURNAL TARBIYAH
}

Terbit dua kali dalam setahun, edisi Januari - Juni dan Juli - Desember, berisi tulisan atau artikel ilmiah ilmu-ilmu ketarbiyahan, kependidikan dan keislaman baik berupa telaah, konseptual, hasil penelitian, telaah buku dan biografi tokoh

\section{Penanggung Jawab}

Dekan Fakultas Ilmu Tarbiyah dan Keguruan UIN Sumatera Utara Medan

\section{Ketua Penyunting}

Mesiono

\author{
Penyunting Pelaksana \\ Junaidi Arsyad \\ Sakholid Nasution \\ Eka Susanti \\ Sholihatul Hamidah Daulay \\ Maryati Salmiah
}

\section{Penyunting Ahli}

Firman (Universitas Negeri Padang, Padang)

Naf'an Tarihoran (Institut Agama Islam Negeri Sultan Maulana Hasanuddin, Banten) Jamal (Universitas Negeri Bengkulu, Bengkulu)

Hasan Asari (Universitas Islam Negeri Sumatera Utara, Medan)

Fachruddin Azmi (Universitas Islam Negeri Sumatera Utara, Medan)

Ibnu Hajar (Universitas Negeri Medan, Medan)

Khairil Ansyari (Universitas Negeri Medan, Medan)

Saiful Anwar (Institut Agama Islam Negeri Raden Intan, Lampung)

\section{Desain Grafis}

Suendri

\section{Sekretariat}

Reflina

Nurlaili

Sahlan 


\title{
MOTIVASI KERJA DAN LINGKUNGAN BELAJAR DALAM UPAYA PENINGKATAN PROSES PEMBELAJARAN
}

\author{
Ali Nurdin \\ Universitas Islam Negeri Syarif Hidayatullah, Jakarta, Indonesia \\ Email: alio10655@yahoo.com
}

DOI : 10.30829/tar.v25i2.367

Diterima : 18 Oktober 2018

Diterbitkan : 15 Desember 2018

\begin{abstract}
Abstrak: Penelitian ini bertujuan untuk mendapatkan informasi dan gambaran secara jelas mengenai hubungan motivasi kerja dan lingkungan belajar terhadap proses pembelajaran di sekolah. Penelitian menggunakan metode kuantitatif melalui analisis korelasi dan analisis regresi. Penelitian dilakukan di Sekolah Menengah Pertama di Ciputat, Tangerang Selatan, Banten, data penelitian dikumpulkan dengan menggunakan instrument (angket) berkaitan dengan motivasi kerja, lingkungan belajar dan proses pembelajaran. Penelitian ini mendapati bahwa motivasi kerja memiliki hubungan positif terhadap proses pembelajaran di sekolah, begitu pula dengan lingkungan belajar yang memiliki hubungan positif terhadap proses pembelajaran di sekolah, dengan demikian maka perbaikan dan peningkatan kualitas proses pembelajaran dapat dilakukan dengan adanya perhatian terhadap motivasi kerja serta penciptaan lingkungan belajar yang baik di sekolah.
\end{abstract}

Kata Kunci: Motivasi Kerja, Lingkungan Belajar, Proses Pembelajaran

Abstract: This research aims to obtain information and a clear picture of the relationship between work motivation and learning environment towards the learning process in school. Research uses quantitative methods through correlation analysis and regression analysis. The study was conducted at the Junior High School in Ciputat, South Tangerang, Banten, the research data was collected by using instruments (questionnaires) related to work motivation, learning environment and learning process. This study found that work motivation has a positive relationship to the learning process in school, as well as a learning environment that has a positive relationship to the learning process in school, thus improving and improving the quality of the learning process can be done with attention to work motivation and the creation of the environment good study at school.

Keywords: Work Motivation, Learning Environment, Learning Process 


\section{Pendahuluan}

Peranan guru dalam meningkatkan kualitas pendidikan di sekolah sangat strategis. Walaupun perkembangan teknologi cukup pesat, sampai saat ini peranan guru sebagai pendidik, pengajar, dan pelatih belum tergantikan. Guru dalam pengertian konvensional adalah orang yang bertanggungjawab terhadap proses pembelajaran di kelas. Peranan guru dalam proses pembelajaran meliputi banyak hal, yakni: mengajar, melatih, membimbing, pemimpin kelas, dan berbagai peran lainnya. Sejatinya guru adalah sebagai penjamin mutu pendidikan yang paling terdepan.

Untuk mewujudkan pendidikan yang bermutu, maka tenaga pendidik dan kependidikan yang professional menjadi kata kunci (Supriadi, 1999). keberhasilan pembaharuan sekolah sangat ditentukan oleh gurunya, karena guru adalah pemimpin pembelajaran, fasilitator, dan sekaligus merupakan pusat inisiatif pembelajaran (Mulyasa, 2007). Kedudukan guru sebagai tenaga profesional berfungsi untuk meningkatkan martabat dan peran guru sebagai agen pembelajaran dan berfungsi untuk meningkatkan mutu pendidikan nasional.

Proses pembelajaran dalam sekolah dapat memberikan dampak terhadap mutu pendidikan disekolah, proses pembelajaran yang baik memiliki kualitas terlaksana oleh guru yang memiliki kualitas dan kinerja yang baik. Dalam meningkatkan proses belajar mengajar dan prestasi siswa seorang guru haruslah mempunyai kinerja yang baik. Kinerja mengandung makna hasil kerja. menurut Djudju Sudjana dalam bukunya Metode dan Teknik Pembelajaran Partisipatif (2000), dikemukakan bahwa pembelajaran dapat diberi arti setiap upaya yang sistematik dan disengaja oleh pendidik untuk menciptakan kondisi-kondisi agar peserta didik melakukan kegiatan belajar. Dalam kegiatan ini terjadi interaksi edukatif antara dua pihak, yaitu peserta didik yang melakukan kegiatan belajar dengan pendidik yang melakukan kegiatan membelajarkan.

Pembelajaran menurut Undang-undang RI nomor 20 tahun 2003 adalah proses interaksi peserta didik dengan pendidik dan sumber belajar pada suatu lingkungan belajar. Sistem pendidikan yang ideal menggunakan paradigma pembelajaran yang berpusat pada siswa. Oleh karena itu tugas guru adalah memfasilitasi siswa belajar. Duffy dan Roehler (1989) mengatakan apa yang dilakukan guru agar proses belajar mengajar berjalan lancar, bermoral dan membuat siswa merasa nyaman merupakan bagian dari aktivitas mengajar, juga secara khusus mencoba dan berusaha untuk mengimplementasikan kurikulum dalam kelas.

Kelangsungan proses pembelajaran menurut Gordon dikutip Hariani dan Muhadjir, (1980) yang mengacu pada profil kemampuan dasar guru, terdiri dari (1) 
Kemampuan menguasai bahan, (2) Kemampuan mengelola program belajar mengajar, (3) Kemampuan mengolah kelas, (4) Kemampuan menggunakan media, (5) Kemampuan menguasai landasan-landasan pendidikan, (6) Kemampuan mengelola interaksi belajar mengajar, (7) Kemampuan menilai prestasi siswa untuk pendidikan dan pengajaran, (8) Kemampuan mengenai fungsi dan program pelayanan bimbingan dan penyuluhan, (9) Kemampuan mengenal memahami prinsip-prinsip guna keperluan pengajaran.

Cece wijaya dan Rusyam, (1992) mengatakan bahwa guru merupakan pendidik dan pengajar tokoh teladan bahkan tokoh identifikasi diri, oleh karena itu guru seyogyanya mempunyai perilaku yang memadai untuk dapat mengembangkan diri siswa secara utuh. Guru merupakan sosok yang dipandang sebagai orang yang memiliki pengaruh perilaku anak didiknya (Triatna, 2008). Untuk itu seorang guru membutuhkan dorongan dalam diri untuk memperbaiki diri sehingga mampu untuk menjalankan tugas dan tanggung jawabnya sebagai seorang tenaga pendidik. Dorongan dalam diri guru untuk mengembangkan kualitas diri dapat disebabkan oleh berbagai faktor salah satunya kebutuhan diri. Menurut Wursanto (2006) dalam teori pengharapan motivasi kerja seseorang sangat ditentukan tujuan khusus yang akan dicapai orang yang bersangkutan, yaitu upah atau gaji yang sesuai, keamanan kerja yang terjamin, kehormatan dan pengakuan, perlakuan yang adil, pimpinan yang cakap, jujur, dan berwibawa, serta suasana kerja yang menarik, jabatan yang menarik.

\section{Proses Pembelajaran}

Pembelajaran merupakan proses kegiatan belajar mengajar yang juga berperan dalam menentukan keberhasilan belajar siswa. Dari proses pembelajaran itu akan terjadi sebuah kegiatan timbal balik antara guru dengan siswa untuk menuju tujuan yang lebih baik. Oleh karena itu, proses pembelajaran musik yang tepat di ekstrakurikuler band sangat dibutuhkan dalam kegiatan berkesenian untuk menghasilkan sebuah karya musik (lagu) melalui aransemen yang pada akhirnya lagu tersebut terkesan baru dan siswa mampu untuk membawakan musik dengan baik. Untuk melakukan sebuah proses pembelajaran, terlebih dahulu harus dipahami pengertian dari kata pembelajaran. Proses pembelajaran adalah proses yang di dalamnya terdapat kegiatan interaksi antara gurusiswa dan komunikasi timbal balik yang berlangsung dalam situasi edukatif untuk mencapai tujuan belajar (Rustaman, 2001). Dalam proses pembelajaran, guru dan siswa merupakan dua komponen yang tidak bisa dipisahkan. Antara dua komponen tersebut harus terjalin interaksi yang salingmenunjang agar hasil belajar siswa dapat tercapai secara optimal. 
Gagne dan Briggs dalam (Djamarah, 2010) pembelajaran merupakan suatu sistem yang bertujuan untuk membantu proses belajar anak didik, yang dirancang, sedemikian rupa untuk mendukung terjadinya proses belajar anak didik yang bersifat internal.

Menurut (Rooijakkers,1991) bahwa proses pembelajaran merupakan suatu kegiatan belajar mengajar menyangkut kegiatan tenaga pendidik, kegiatan peserta didik, pola dan proses interaksi tenaga pendidik dan peserta didik dan sumber belajar dalam suatu lingkungan belajar dalam kerangka keterlaksanaan program pendidikan. Hal ini diperkuat oleh (Winkel, 1991) memberikan gambaran bahwa proses pembelajaran adalah suatu aktivitas psikis atau mental yang berlangsung dalam interaksi aktif dalam lingkungan, yang menghasilkan perubahan-perubahan pengetahuan, pemahaman, keterampilan dan nilai sikap.

Dari beberapa pendapat tersebut dapat disimpulkan bahwa proses pembelajaran adalah segala upaya bersama antara guru dan siswa untuk berbagi dan mengolah informasi, dengan harapan pengetahuan yang diberikan bermanfaat dalam diri siswa dan menjadi landasan belajar yang berkelanjutan, serta diharapkan adanya perubahanperubahan yang lebih baik untuk mencapai suatu peningkatan yang positif yang ditandai dengan perubahan tingkah laku individu demi terciptanya proses belajar mengajar yang efektif dan efisien. Sebuah proses pembelajaran yang baik akan membentuk kemampuan intelektual, berfikir kritis dan munculnya kreatifitas serta perubahan perilaku atau pribadi seseorang berdasarkan praktik atau pengalaman tertentu.

\section{Lingkungan Belajar}

Motivasi menurut Uno (2011) adalah kekuatan baik dari dari dalam maupun dari luar yang mendorong seseorang untuk bekerja dalam rangka mencapai tujuan tertentu yang telah ditetapkan sebelumnya. Pendapat Danim (2012) motivasi merupakan setiap daya gerak atau daya dorong yang muncul pada diri individu untuk secara sadar mengabdikan diri bagi pencapaian tujuan organisasi. Pada prakteknya peran guru kurang optimal termasuk pada dimensi subjektivitasnya. Guru kurang terarah, kurang mampu bertahan terhadap situasi pembelajaran yang banyak tekanan termasuk tekanan untuk mengoptimalkan mutu pada proses pembelajaran (Budiawati, 2017).

Selain itu faktor lingkungan akan berpengaruh terhadap aktivitas pembelajaran di sekolah, baik lingkungan fisik maupun lingkungan non fisik. Sekolah memiliki lingkungan belajar yang aman, tertib, dan nyaman sehingga proses belajar mengajar dapat berlangsung dengan nyaman (enjoyable learning). Sartain dalam Purwanto (2011) berpendapat bahwa lingkungan meliputi semua kondisi-kondisi dalam dunia ini yang 
dalam cara-cara tertentu mempengaruhi tingkah laku kita, pertumbuhan-pertumbuhan, perkembangan atau life processes kita kecuali gen-gen.

Slameto (2003) mengemukakan bahwa lingkungan belajar siswa yang berpengaruh terhadap belajar siswa terdiri dari lingkungan keluarga, lingkungan sekolah dan lingkungan masyarakat. Lingkungan belajar sangat menentukan dalam kegiatan pendidikan pengajaran. Menurut Hamalik, (2004) lingkungan adalah segala sesuatu yang yang ada di alam sekitar yang memiliki makna atau pengaruh tertentu kepada individu. Ditambahkan pula lingkungan belajar menurut Muhammad Saroni (2006), adalah segala sesuatu yang berhubungan dengan tempat proses pembelajaran dilaksanakan.

Lingkungan sangat berperan dalam ketercapaian aktivitas pembelajaran, seperti yang diungkapkan Indra Djati Sidi (2005), lingkungan belajar sangat berperan dalam menciptakan suasana belajar menyenangkan. Lingkungan dapat meningkatkan keaktifan belajar, oleh karena itu lingkungan belajar perlu di tata dengan sebaik mungkin.

Dalam lingkungan sekolah, sebagai salah satu lingkungan belajar Menurut Slameto (2003) faktor sekolah yang mempengaruhi belajar mencangkup metode mengajar, kurikulum, relasi guru dengan siswa, relasi guru dengan siswa, relasi siswa dengan siswa, disiplin sekolah, alat pembelajaran, waktu sekolah, standar pelajaran, keadaan gedung, metode belajar dan tugas rumah. Tanpa adanya lingkungan belajar yang mendukung proses pembelajaran maka dapat menghasilkan proses pembelajaran yang kurang berkualitas, sehingga untuk menghasilkan proses pembelajaran yang berkualitas memerlukan lingkungan belajar yang nyaman, kondusif sehingga aktivitas pembelajaran akan berjalan dengan baik.

Untuk itu dapat dikatakan bahwa dalam menghasilkan kualitas proses pembelajaran yang tinggi akan dapat dilaksanakan dengan adanya motivasi kerja dalam diri guru serta adanya lingkungan belajar yang kondusif, dengan demikian dalam penelitian ini ingin mengkaji dan menganalisis hubungan motivasi kerja guru dan lingkungan belajar terhadap proses pembelajaran di sekolah.

\section{Motivasi Kerja}

Setiap organisasi ingin mencapai tujuannya. Untuk mencapai tujuan tersebut, peran manusia yang terlibat didalamnya sangat penting. Untuk menggerakkan manusia agar sesuai dengan yang dikehendaki organisasi, maka harus dipahami motivasi manusia yang bekerja di dalam organisasi tersebut, karena motivasi inilah yang menentukan perilaku orang-orang bekerja atau dengan kata lain perilaku merupakan cerminan yang 
paling sederhana dari motivasi. Untuk itu agar perilaku manusia sesuai dengan tujuan organisasi maka harus ada perpaduan antara motivasi mereka dan permintaan organisasi.

Kata Motivasi berasal dari kata Latin "Motive" yang berarti dorongan, daya penggerak atau kekuatan yang terdapat dalam diri organisme yang menyebabkan organisme itu bertindak atau berbuat. Selanjutnya diserap dalam bahasa Inggris motivation berarti pemberian motif, penimbulan motif atau hal yang menimbulkan dorongan atau keadaan yang menimbulkan dorongan.

Motivasi tidak dapat diamati secara langsung, tetapi dapat diinterprestasikan dari tingkah lakunya. Motivasi dipandang sebagai perubahan energi dari diri seseorang yang diperlukan yang ditandai dengan munculnya feeling, dan didahului dengan tanggapan terhadap adanya tujuan. Pernyataan ini mengandung tiga pengertian, yaitu: (1) motivasi mengawali terjadinya perubahan energy pada diri setiap individu,(2) motivasi ditandai oleh adanya rasa atau feeling, afeksi seseorang, dan (3) motivasi dirangsang karena adanya tujuan.

Sementara (Wahjosumidjo, 2001) motivasi kerja dapat diartikan sebagai suatu proses psikologi yang mencerminkan interaksi antara sikap, kebutuhan, persepsi, dan keputusan yang terjadi pada diri sesorang. Proses psikologi timbul diakibatkan oleh faktor di dalam diri seseorang itu sendiri yang disebut intrinsic dan extrinsic. Faktor di dalam diri seseorang bisa berupa kepribadian, sikap, pengalaman dan pendidikan, atau berbagai harapan, cita- cita yang menjangkau ke masa depan sedang faktor dari luar diri dapat ditimbulkan oleh berbagi faktor-faktor lain yang sangat kompleks. Tetapi baik faktor ekstrinsik maupun faktor instrinsik, motivasi timbul karena adanya rangsangan. Tingkah laku bawahan dalam kehidupan organisasi pada dasarnya berorientasi pada tugas. Artinya, bahwa tingkah laku bawahan biasanya didorong oleh keinginan untuk mencapai tujuanharus selalu diamati, diawasi, dan diarahkan dalam kerangka pelaksanaan tugas dalam mencapai tujuan organisasi.

Hasibuan (2010) memberikan pandangan bahwa motivasi mempersoalkan bagaimana caranya mengarahkan daya dan potensi agar mau bekerjasama secara produktif untuk mencapai dan mewujudkan tujuan yang telah ditentukan, mau bekerja dan antusias mencapai hasil yang optimal. Sedangkan Manullang (2000) memberi penguatan bahwa motivasi sebagai pekerjaan yang dilakukan oleh seorang manajer memberikan inspirasi, semangat, dan dorongan kepada orang lain. Dalam hal ini karyawan untuk mengambil tindakan-tindakan. Pemberian dorongan ini bertujuan untuk menggiatkan karyawan agar mereka bersemangat dan dapat mencapai hasil sebagaimana dikehendaki oleh orang tersebut. Hal ini diperkuat oleh Robbins dan Judge 
(2007) mendefinisikan motivasi sebagai proses yang menjelaskan intensitas, arah dan ketekunan usaha untuk mencapai suatu tujuan.

Selanjutnya Mangkunegara (2005) menyatakan: "motivasi terbentuk dari sikap (attitude) karyawan dalam menghadapi situasi kerja di perusahaan (situation). Motivasi merupakan kondisi atau energi yang menggerakkan diri karyawan yang terarah atau tertuju untuk mencapai tujuan organisasi perusahaan. Sikap mental karyawan yang pro dan positif terhadap situasi kerja itulah yang memperkuat motivasi kerjanya untuk mencapai kinerja maksimal".

Motivasi dapat dipengaruhi oleh faktor internal maupun faktor eksternal (Uno, 2008). Begitu pula dengan Ryan and Deci, (2000) yang menyebutkan motivasi dapat disebabkan oleh dua faktor baik faktor dari dalam diri maupun dari luar diri. Menurut Siswanto (2008) motivasi adalah (1) setiap perasaan atau kehendak dan keinginan yang sangat mempengaruhi kemauan individu sehingga individu tersebut didorong untuk berperilaku dan bertindak, (2) pengaruh kekuatan yang menimbulkan perilaku individu, (3) setiap tindakan atau kejadian yang menyebabkan berubahnya perilaku seseorang, (4) proses yang menentukan gerakan atau perilaku individu kepada tujuan.

Berdasarkan pandangan beberapa konsep teori di atas tentang motivasi kerja, terdapat tiga unsur yang merupakan kunci dari motivasi, yaitu: 1) unsur upaya merupakan ukuran intensitas. Dalam hal ini apabila seseorang termotivasi dalam melakukan tugasnya ia akan mencoba sekuat tenaga, agar upaya yang tinggi tersebut menghasilkan kinerja yang tinggi pula. Oleh karena itu, dalam pemberian motivasi terhadap seseorang diperlukan pertimbangan kualitas dan kuantitas yang membangkitkan upaya dan diarahkan pada pencapaian tujuan, 2) unsur tujuan organisasi, dalam suatu organisasi tujuan harus ditetapkan secara jelas. Kejelasan tujuan akan mengarahkan segala aktivitas dan perilaku personal untuk pencapaiannya. Makin jelas tujuan organisasi maka makin mudah setiap personal untuk memahami, dan 3) unsur kebutuhan adalah suatu keadaan internal yang menyebabkan hasil-hasil tertentu tampak menarik, suatu kebutuhan tidak terpuaskan menciptakan keinginan yang mendorong individu untuk mencapainya.

\section{Metode Penelitian}

Penelitian menggunakan metode kuantitatif, metode kuantitatif digunakan untuk menguji besarnya kontribusi variabel bebas (X) terhadap variabel terikat (Y). Menurut McMillan dan Scumacher (2001) Penelitian kuantitif merupakan suatu bentuk penelitian yang mengkaji obyek, gejala, peristiwa atau data yang dapat diukur secara angka (skala, 
indeks, rumus dan sebagainya) dan analisisnya menggunakan statistik. Metode kuantitatif melalui analisis korelasi dan analisis regresi.

Menurut Pratisto (2009) Analisis yang selalu melekat dalam analisis regresi adalah analisis korelasi. Korelasi merupakan istilah yang digunakan untuk mengukur kekuatan hubungan antar variabel (Hasan, 2003). Analisis regresi digunakan terutama untuk tujuan peramalan, dimana dalam model tersebut ada sebuah variabel dependen (tergantung) dan variabel independent (bebas) (Santoso, 2002).

Dalam penelitian ini pada dasarnya dimaksudkan untuk memperoleh gambaran mengenai seberapa besar kontribusi variabel bebas terhadap variabel terikat, terdapat tiga variabel dalam penelitian ini yaitu $\left(\mathrm{X}_{1}\right)$ motivasi kerja, $\left(\mathrm{X}_{2}\right)$ lingkungan belajar, dan $\left(\mathrm{Y}_{1}\right)$ proses pembelajaran.

Data penelitian membutuhkan sumber yang akurat. Sumber data tersebut merupakan sumber data yang sesuai dengan penelitan yang sedang dilakukan. Sumber data penelitian yang penulis gunakan dalam penelitian ini adalah para guru di Sekolah Menengah Pertama di Ciputat, Tangerang Selatan, Banten. Populasi dalam penelitian ini adalah seluruh guru yang bertugas di Sekolah Menengah Pertama di Ciputat, Tangerang Selatan, Banten. Sampel dalam penelitian ini ditetapkan sebanyak 150 orang sampel, pengambilan sampel mengacu kepada pendapat Singarimbun dan Efendi (1989) bahwa sampel besar yang distribusinya normal adalah sampel 30 kasus, dan apabila dianalisis data yang dipakai adalah teknik korelasi maka sampel yang harus diambil minimal 30 kasus. Pengambilan sampel dilakukan dengan menggunakan teknik Random Sampling" atau acak sederhana. Menurut Sugiono (1998) pengambilan sampel secara acak merupakan metode penelitian ukuran sampel dimana setiap populasi mempunyai peluang yang sama untuk menjadi anggota sampel. Ditambahkan pula oleh Sugiarto, dkk (2003) menyatakan bahwa metode pengambilan acak sederhana adalah metode yang digunakan untuk memilih sampel dari populasi dengan cara sedemikian rupa sehingga setiap anggota populasi mempunyai peluang yang sama besar untuk diambil sebagai sampel. Data dikumpulkan dengan menggunakan instrumen penelitian berbentuk angket untuk varibel proses belajar mengajar, motivasi kerja dan lingkungan belajar. Data yang telah terkumpul kemudian diolah menggunakan alat bantu SPSS 16.oo Version serta exel 2007.

\section{Hasil Penelitian}

\section{Hubungan Motivasi Kerja Terhadap Proses Pembelajaran}

Untuk mengetahui hubungan motivasi kerja terhadap proses pembelajaran digunakan analisis regresi dan korelasi. Dari hasil perhitungan analisis regresi sederhana 
pada data variabel. Hubungan motivasi kerja terhadap proses pembelajaran diperoleh arah regresi b sebesar $=0.524$ dan konstanta a sebesar 50.498. Dengan demikian bentuk kedua hubungan tersebut ( $\mathrm{X}_{1}$ dengan $\mathrm{Y}$ ) dapat digambarkan dengan persamaan regresi $\hat{\mathrm{Y}}=50.498+0.524 \mathrm{X}_{1}$. Sebelum digunakan untuk keperluan prediksi, persamaan regresi harus memenuhi syarat uji keberartian (signifikansi) dan uji kelinieran. Untuk mengetahui derajat keberartian dan kelinieran persamaan regresi, dilakukan uji F dan hasilnya disajikan pada tabel 1 berikut ini:

Tabel 1 Analisis Variansi Uji Signifikansi dan Uji Linieritas Regresi

$$
\hat{\mathbf{Y}}=\mathbf{5 0 . 4 9 8}+\mathbf{0 . 5 2 4} \mathrm{X}_{\mathbf{1}}
$$

\begin{tabular}{|l|l|l|l|l|l|l|}
\hline \multicolumn{2}{|l|}{ Model } & Sum of Squares & df & Mean Square & F & Sig. \\
\hline \multirow{2}{*}{1} & Regression & 2886.225 & 1 & 2886.225 & 40.778 & $.0^{\mathrm{b}}{ }^{\mathrm{b}}$ \\
\cline { 2 - 7 } & Residual & 10475.168 & 148 & 70.778 & & \\
\cline { 2 - 7 } & Total & 13361.393 & 149 & & & \\
\hline
\end{tabular}

$*^{*}=$ regresi sangat signifikan (Fhitung40.778 $>F_{\text {tabel }} 6,76$ pada $\alpha=0,01$ )

Berdasarkan hasil analisis varians pengujian signifikansi regresi antara $\mathrm{X}_{1}$ dengan Y pada tabel 1, diketahui Fhitung $>$ Ftabel $(40.778>6,76)$ pada $\alpha=0$,01. Dapat disimpulkan bahwa regresi $\mathrm{Y}$ atas $\mathrm{X}_{1}$ sangat signifikan. Harga $\mathrm{F}$ tuna cocok hasil perhitungan Fhitung< dari $F_{\text {tabel }}(1,576<2.05)$, maka bentuk regresi $Y$ atas $X_{1}$ adalah liniear. Dapat disimpulkan $\hat{\mathrm{Y}}=50.498+0.524 \mathrm{X}_{1}$ sangat signifikan dan liniear. Regresi ini mengandung arti bahwa apabila motivasi kerja naik satu unit, maka akan berkontribusi terhadap peningkatan proses pembelajaran sebesar 0.524 unit pada konstanta 50.498 .

Kekuatan hubungan variabel $\mathrm{X}_{1}$ terhadap $\mathrm{Y}$ ditunjukkan oleh koefisien korelasi $\mathrm{r}_{\mathrm{y} 1}$ sebesar $=0.465$. Uji keberartian koefisien korelasi dengan uji $t$ didapat harga thitung sebesar 6.389. Sedangkan $t_{\text {tabel }}$ pada $\alpha=0,05$; di dapat harga $t_{\text {tabel }}=1,65$, pada $\alpha=0,01$ adalah 2,33. Maka dapat disimpulkan bahwa terdapat hubungan positif dan signifikan motivasi kerja terhadap proses pembelajaran teruji kebenarannya, dengan perkataan lain makin tinggi motivasi kerja, makin tinggi kontribusi dan pengaruhnya terhadap proses pembelajaran.

Selanjutnya diadakan analisis terhadap koefisien determinasi. Koefisien determinasi merupakan kuadrat dari koefisien korelasi antara variabel $\mathrm{X}_{1}$ dengan variabel $Y$. Koefisien determinasi $X_{1}$ dengan $Y$ sebesar $\left(r_{y 1}\right)^{2}=(0.465)^{2}=0,216$. Ini berarti 
bahwa 21.6\% variasi yang terjadi pada proses pembelajaran dapat dijelaskan oleh motivasi kerja melalui regresi $\hat{Y}=50.498+0.524 \mathrm{X}_{1}$. Dengan demikian dapat disimpulkan bahwa apabila motivasi kerja tinggi, maka proses pembelajaran tinggi, sebaliknya jika motivasi kerja rendah, maka proses pembelajaran rendah.

\section{Hubungan Lingkungan Belajar Terhadap Proses Pembelajaran}

Untuk mengetahui hubungan lingkungan belajar terhadap proses pembelajaran digunakan analisis regresi dan korelasi. Dari hasil perhitungan analisis regresi sederhana pada data variabel lingkungan belajar atas proses pembelajaran diperoleh arah regresi b sebesar $=0.735$ dan konstanta a sebesar 32.581. Dengan demikian bentuk kedua hubungan tersebut $\left(\mathrm{X}_{2}\right.$ dengan $\left.\mathrm{Y}\right)$ dapat digambarkan dengan persamaan regresi $\hat{\mathrm{Y}}=$ $32.581+0.735 \mathrm{X}_{2}$. Sebelum digunakan untuk keperluan prediksi, persamaan regresi harus memenuhi syarat uji keberartian (signifikansi) dan uji kelinieran. Untuk mengetahui derajat keberartian dan kelinieran persamaan regresi, dilakukan uji F dan hasilnya disajikan pada tabel 2 berikut ini:

Tabel 2 Analisis Variansi Uji Signifikansi dan Uji Linieritas Regresi $\hat{\mathbf{Y}}=$ $32.581+0.735 X_{2}$

\begin{tabular}{|l|l|l|l|l|l|l|}
\hline \multicolumn{2}{|l|}{ Model } & Sum of Squares & df & Mean Square & F & Sig. \\
\hline \multirow{3}{*}{1} & Regression & 7282.036 & 1 & 7282.036 & 177.279 &.${.000^{b}}^{\text {f }}$ \\
\cline { 2 - 7 } & Residual & 6079.358 & 148 & 41.077 & & \\
\cline { 2 - 6 } & Total & 13361.393 & 149 & & & \\
\hline
\end{tabular}

Berdasarkan hasil analisis varians pengujian signifikansi regresi antara $\mathrm{X}_{2}$ dengan Y pada tabel 2, diketahui Fhitung $>$ Ftabel $(177.279>6,76)$ pada $\alpha=0$,01. Dapat disimpulkan bahwa regresi Yatas $\mathrm{X}_{2}$ sangat signifikan. Harga $\mathrm{F}$ tuna cocok hasil perhitungan Fhitung< Ftabel $(1.717 \leq 2.05)$, maka bentuk regresi $\mathrm{Y}$ atas $\mathrm{X}_{2}$ adalah liniear. Dapat disimpulkan $\hat{\mathrm{Y}}=$ $32.581+0.735 \mathrm{X}_{2}$ sangat signifikan dan linier. Regresi ini mengandung arti bahwa apabila lingkungan belajar naik satu unit, maka proses pembelajaran meningkat 0.735 unit pada konstanta 32.581 . 
Kekuatan hubungan antara variabel $\mathrm{X}_{2}$ dengan $\mathrm{Y}$ ditunjukkan oleh koefisien korelasi $\mathrm{r}_{\mathrm{y} 2}$ sebesar $=0,738$. Uji keberartian koefisien korelasi dengan uji t didapat harga thitung sebesar 13.304. Sedangkan tabel pada $\alpha=0,01$ di dapat harga tabel $=2,33$. maka dapat disimpulkan terdapat kontribusi lingkungan belajar terhadap proses pembelajaran. Dengan demikian dapat diketahui bahwa terdapat hubungan positif lingkungan belajar terhadap proses pembelajaran teruji kebenarannya, dengan perkataan lain makin tinggi lingkungan belajar, makin tinggi kontribusi dan hubungannya terhadap peningkatan proses pembelajaran di sekolah.

Selanjutnya diadakan analisis terhadap koefisien determinasi. Koefisien determinasi merupakan kuadrat dari koefisien korelasi antara variabel $\mathrm{X}_{2}$ dengan variabel $\mathrm{Y}$. Koefisien determinasi $\mathrm{X}_{2}$ dengan $\mathrm{Y}$ sebesar $\left(\mathrm{r}_{\mathrm{y} 2}\right)^{2}=(0,738)^{2}=0,542$. Ini berarti bahwa $54.2 \%$ variasi yang terjadi pada proses pembelajaran dapat dijelaskan lingkungan belajar melalui regresi $\hat{Y}=32.581+0.735 \mathrm{X}_{2}$. Dengan demikian maka dapat disimpulkan bahwa lingkungan belajar memiliki hubungan yang positif dan signifikan terhadap proses pembelajaran di sekolah, semakin baik lingkungan belajar yang terbentuk di sekolah maka akan semakin baik pula proses pembelajaran yang terlaksana.

\section{Hubungan Motivasi Kerja dan Lingkungan Belajar secara bersama-sama Terhadap Proses Pembelajaran}

Untuk mencari hubungan motivasi kerja dan lingkungan belajar secara bersamasama terhadap proses pembelajaran di sekolah, maka dalam penelitian ini menggunakan analisis korelasi dan regresi jamak.

Perhitungan regresi jamak data variabel proses pembelajaran menghasilkan arah regresi $a_{1}$ sebesar, 0.035 untuk variabel $\mathrm{X}_{1}$ (motivasi kerja), $\mathrm{a}_{2}$ sebesar 0.716 untuk variabel $\mathrm{X}_{2}$ (lingkungan belajar), serta konstanta a sebesar 31.268. Bentuk antar variabel bebas dengan variabel terikat tersebut dapat digambarkan oleh persamaan regresi $\hat{\mathbf{Y}}=$ 31.268+o.035 $X_{1}+0.716 X_{2}$. Sebelum digunakan untuk keperluan prediksi, persamaan regresi ini harus dilakukan uji keberartian regresi. Untuk mengetahui derajat keberartian persamaan regresi jamak, dilakukan uji $\mathrm{F}$ dan hasilnya disajikan pada tabel 3 sebagai berikut: 
Tabel 3 Analisis Varians Regresi Linear Jamak $\hat{Y}=\mathbf{3 1 . 2 6 8}+0.035 X_{1}+0.716 X_{2}$.

\begin{tabular}{|l|l|l|l|l|l|l|}
\hline \multicolumn{2}{|l|}{ Model } & Sum of Squares & df & Mean Square & F & Sig. \\
\hline \multirow{3}{*}{1} & Regression & 7290.403 & 2 & 3645.201 & 88.263 &. $.000^{b}$ \\
\cline { 2 - 7 } & Residual & 6070.990 & 147 & 41.299 & & \\
\cline { 2 - 7 } & Total & 13361.393 & 149 & & & \\
\hline
\end{tabular}

a. Dependent Variable: Proses Pembelajaran

b. Predictors: (Constant), Lingkungan Belajar, Motivasi Kerja

$* *=$ regresi sangat signifikan (Fhitung88.263 $>$ Ftabel 3,88 pada $\alpha=0,01$ )

Berdasarkan analisis varians regresi jamak pada tabel 3 di atas diketahui harga $F_{\text {hitung }}>F_{\text {tabel }}(88.263>3,88)$ pada $\alpha=0,01$, maka dapat disimpulkan regresi jamak $\hat{Y}=$ 31.268+0.035 $\mathrm{X}_{1}+0.716 \mathrm{X}_{2}$, sangat signifikan. Kekuatan korelasi jamak antara variabel $\mathrm{X}_{1}$, $\mathrm{X}_{2}$ dengan variabel $\mathrm{Y}$ diperoleh koefisien korelasi $\mathrm{R}=0,739$. Hasil uji keberartian dengan uji F, diperoleh Fhitung = 13.344. Maka dapat disimpulkan bahwa koefisien korelasi jamak $\left(\mathrm{R}_{\mathrm{y} 12}\right)$ dalam penelitian ini sangat signifikan pada $\alpha=0,01$. Temuan ini membuktikan bahwa terdapat hubungan positif motivasi kerja, dan lingkungan belajar secara bersamasama terhadap proses pembelajaran, teruji kebenarannya.

Koefisien determinasi antara variabel $\left(\mathrm{X}_{1}, \mathrm{X}_{2}\right)$ dengan variabel terikat $(\mathrm{Y})$ adalah sebesar $\mathrm{R}^{2}=(0,739)^{2}=0,546$ ini menunjukkan bahwa $54.6 \%$ variasi yang terjadi pada variabel proses pembelajaran dapat dijelaskan secara bersama-sama oleh variabel motivasi kerja, dan lingkungan belajar secara bersama-sama melalui persamaan regresi $\hat{\mathrm{Y}}=31.268+0.035 \mathrm{X}_{1}+0.716 \mathrm{X}_{2}$. Variansi sisanya sebesar 0,454 atau 45.4\% dijelaskan oleh variabel lainnya.

\section{Pembahasan}

Kajian ini mendapati bahwa motivasi kerja memiliki hubungan positif dan signifikan terhadap proses pembelajaran di sekolah, penelitian ini menunjukkan bahwa proses pembelajaran akan terlaksana dengan baik apabila seorang guru memiliki motivasi untuk bekerja, dengan adanya motivasi kerja dalam diri guru maka guru akan berusaha untuk melaksanakan aktivitas pembelajaran semaksimal mungkin dengan harapan akan mencapai tujuan yang diinginkan. Hasil ini sejalan dengan pernyataan Uno (2011) bahwa "motivasi merupakan proses pengerahan dan penguatan motif itu untuk diaktualisasikan dalam perbuatan nyata, sebagai sebuah kondisi motivasi bersifat dinamis. Hasil penelitian memperkuat konsep mengenai motivasi yang dikemukakan 
mashlow (1947) bahwa seseorang memiliki kebutuhan untuk mengembangkan kepribadian, kebebasan untuk memilih dan kualitas positif (seperti peka terhadap orang lain).

Motivasi kerja sangat penting untuk dimiliki guru dalam upaya pengembangan dan peningkatan kualitas proses pembelajaran, hal ini disebabkan menyangkut kualitas sumber daya manusia di sekolah, seperti yang diungkapkan oleh Mathis dan Jackson (2001) motivasi merupakan hal terpenting karena kinerja, reaksi terhadap kompensasi, dan perhatian Sumber Daya Manusia (SDM) lainnya berhubungan dengan motivasi tersebut. Motivasi merupakan kemauan untuk berjuang atau berusaha ke tingkat yang lebih tinggi menuju tercapainya tujuan organisasi (Muchlas, 2005). Tujuan motivasi adalah meningkatkan produktivitas kerja karyawan (Hasibuan, 2011). Dengan demikian adanya motivasi kerja dalam diri guru akan memberikan dampak yang baik dalam aktivitas pembelajaran yang dilakukan guru di sekolah, yaitu sebagai pengelolan proses pembelajaran.

Hasibuan, (2003) mengemukakan dalam memotivasi pegawai, pimpinan hendaknya menyediakan peralatan menciptakan suasana pekerjaan yang baik, dan memberikan kesempatan untuk promosi. Beberapa kegiatan yang dapat dilakukan kepalasekolah untuk meningkatkan motivasi kerjaguru antara lain menerapkan manajemen yang terbuka, menerapkan deskripsi pekerjaan dengan tugas dan fungsi yangjelas, menerapkan hubungan yang baik, menerapkan pengawasan yang berkelanjutan dan menyeluruh, dan perludilakukan program evaluasi (Karwati \& Priansa, 2013).

David McClelland (dalam Robbins, 1996 : 217) berpendapat bahwa: A motive is the redintegration by a cue of a change in an affective situation, yang berarti motif merupakan implikasi dari hasil pertimbangan yang telah dipelajari (redintegration) dengan ditandai suatu perubahan pada situasi afektif. Sumber utama munculnya motif adalah dari rangsangan (stimulasi) perbedaan situasi sekarang dengan situasi yang diharapkan, sehingga tanda perubahan tersebut tampak pada adanya perbedaan afektif saat munculnya motif dan saat usaha pencapaian yang diharapkan.

Pendapat ini memberikan keyakinan bahwa motivasi yang tinggi akan memberikan peningkatan yang signifikan terhadap kinerja pengawas. Motivasi merupakan dorongan dan kekuatan dalam diri seseorang untuk melakukan tujuan tertentu yang ingin dicapainya. Pernyataan ahli tersebut, dapat diartikan bahwa yang dimaksud tujuan adalah sesuatu yang berada di luar diri manusia sehingga kegiatan manusia lebih terarah karena seseorang akan berusaha lebih semangat dan giat dalam 
berbuat sesuatu. Pengawas dapat memberikan motivasi guru dengan melihat suasana emosional guru tersebut. Menurutnya, motivasi berprestasi dimiliki oleh setiap orang, sedangkan intensitasnya tergantung pada kondisi mental orang tersebut.

Selain itu lingkungan belajar juga memiliki hubungan yang positif dan signifikan terhadap proses pembelajaran di sekolah. lingkungan belajar yang baik akan memberikan kenyamanan dan ketentraman dalam aktivitas pembelajaran yang dilakukan. Sekolah sebagai wadah setiap aktivitas pembelajaran menjadi salah satu lingkungan belajar yang dapat mempengaruhi kualitas proses pembelajaran. Sekolah merupakan lembaga pendidikan formal yang sistematis melaksanakan program bimbingan, pengajaran, dan latihan dalam rangka membantu siswa agar mampu mengembangkan potensinya. Hasil penelitian yang dilakukan di Malaysia berkaitan dengan iklim kerja menunjukkan bahwa sekolah-sekolah yang berprestasi di malaysia menunjukkan iklim kerja yang besifat terbuka (Marzuki, 1997). Ditambahkan pula dalam hasil penelitian yang dilakukan oleh Jhonson dan Jhonson (1995) diketahui bahwa suasana belajar sekolah dengan faktor-faktor yang ada di dalamnya ditemukan hubungan positif dan paralel antara iklim belajar sekolah dengan efektivitas sekolah.

Hamalik (2004), Lingkungan (environment) sebagai dasar pengajaran adalah faktor kondisional yang mempengaruhi tingkah laku individu dan merupakan faktor belajar yang penting. Lingkungan belajar merupakan faktor eksternal dalam proses pembelajaran di sekolah, lingkungan belajar sangat mempengaruhi pada kegiatan proses pembelajaran, lingkungan belajar yang baik merupakan lingkungan belajar yang mampu memberikan pengaruh positif terhadap proses pembelajaran, kenyamanan yang dirasakan oleh siswa dalam lingkungan belajar akan memberikan pengaruh positif, memberikan motivasi yang tinggi dimana akan mendorong untuk siswa berprestasi.

\section{Simpulan}

Berdasarkan hasil analisis data, temuan dan pembahasan penelitian maka dapat diambil sebuah kesimpulan sebagai berikut:

1. Terdapat hubungan positif dan signifikan motivasi kerja terhadap proses pembelajaran teruji kebenarannya, dengan perkataan lain makin tinggi motivasi kerja, makin tinggi kontribusi dan pengaruhnya terhadap proses pembelajaran.

2. Terdapat hubungan positif lingkungan belajar terhadap proses pembelajaran teruji kebenarannya, dengan perkataan lain makin tinggi lingkungan belajar, makin tinggi kontribusi dan hubungannya terhadap peningkatan proses pembelajaran di sekolah. 
3. Terdapat hubungan positif motivasi kerja, dan lingkungan belajar secara bersamasama terhadap proses pembelajaran, teruji kebenarannya.

\section{Implikasi}

Dalam penelitian ini di ketahui bahwa motivasi kerja dan lingkungan belajar memiliki hubungan yang positif terhadap proses pembelajaran di sekolah. Dengan demikian maka pelaksanaan proses pembelajaran akan berhasil apabila memiliki motivasi kerja guru serta adanya lingkungan belajar yang kondusif di sekolah. Guru dalam pelaksanaan aktivitas pembelajaran di sekolah membutuhkan motivasi kerja yang tinggi, proses pembelajaran membutuhkan konsentrasi yang tinggi serta kreatifitas dan inovasi maupun tenaga, oleh karena itu motivasi kerja guru dalam proses pembelajaran harus ditumbuhkan dan ditingkatkan, sehingga guru sebagai pengelola proses pembelajaran akan mampu dan berupaya memberikan kualitas dan profesionalisme dalam pelaksanaan proses pembelajaran di sekolah.

Dari hasil penelitian pula di ketahui bahwa lingkungan belajar memiliki hubungan yang lebih besar bila dibandingkan dengan motivasi kerja, hal ini menunjukkan bahwa lingkungan belajar memiliki pengaruh yang besar pada keberlangsungkan proses pembelajaran di sekolah. Dalam penelitian diketahui lingkungan belajar dalam keadaan baik, dimana lingkungan belajar memberikan kontribusi yang positif, adanya peran aktif dari lingkungan belajar dalam meningkatkan kualitas pendidikan dalam sekolah. lingkungan belajar memberikan sumbangan terhadap peningkatan proses pembelajaran di sekolah, lingkungan belajar merupakan salah satu faktor yang memberikan pengaruh terhadap proses pembelajaran dan menentukan mutu pendidikan di sekolah. Lingkungan belajar akan menjadi kondusif bila adanya kerjasama yang baik diantara komponen lingkungan belajar, lingkungan belajar merupakan salah satu faktor yang berperan dalam keberlangsungan aktivitas proses pembelajaran di dalam sekolah.

\section{Daftar Pustaka}

Anwar Prabu Mangkunegara. (2005). Sumber Daya Manusia perusahaan. Remaja Rosdakarya: Bandung.

Budiawati, J (2017). Iklim, Kepuasan, dan Motivasi Kerja Guru Di Sekolah Dasar Bpk Penabur. Jurnal Administrasi Pendidikan Vol.XXIV No.1. 36-46.

Cece Wijaya dan Rusyam, A.T (1992). Kemampuan Dasar Guru Dalam Proses BelajarMengajar. Bandung: Remaja Rosdakarya. 
Danim, Sudarwan. (2012). Motivasi Kepemimpinan dan Efektivitas Kelompok. Jakarta : Rineka Cipta.

Djamarah. S. B, Zain. A. (2010). Strategi Belajar Mengajar. Jakarta: Rineka Cipta.

Duffy and Roehler. (1989). Improving Classroom Reading Instruction. New York: Radom Hause.

Hamalik, Oemar. (2004). Proses Belajar Mengajar. Jakarta Bumi Aksara.

Hariani, M dan Noeng Muhadjir. (1980). EvaluasiKemampuan Mengajar. Jakarta : P$3 \mathrm{G}$ Dikbud.

Hasan Iqbal.(2003). Pokok-Pokok Materi Statistik 1. Jakarta: PT Bumi Aksara.

Hasibuan, (2010). Manajemen Sumber Daya Manusia, Jakarta: Bumi Aksara.

Hasibuan, Malayu S.P. (2003). Manajemen Sumber Daya Manusia. Jakarta: PT Bumi Aksara.

Hasibuan, Malayu S.P., (2011). Manajemen Sumber Daya Manusia. Jakarta: Bumi Aksara.

http://eprints.uny.ac.id/8120/3/BAB\%202-06208241034.pdf di Akses Tanggal 30 Agustus 2018.

Johnson, D. W., \& Johnson, R. T. (1995). Social Interdependence - Cooperative Learning in Education. In B. Bunker \& J. Z. Rubin (Eds.), Conflict, Cooperation, and Justice (pp. 205-251). San Francisco: Jossey-Bass Publishers.

Karwati, Euis dan Joni Priansa, Donni. (2013). Kinerja dan Profesionalisme Kepala Sekolah Membangun Sekolah Yang Bermutu. Bandung: Alfabeta.

Manullang,M. (2005). Dasar-Dasar Manajemen. Bandung: Cita Pustaka.

Mashlow, A.H. (1947). Theory of Human Motivation. [Online]. Diakses dari http://citeseerx.ist.psu. Eduviewdoc/download?doi =10.1.1.318.2317\& rep=rep1\&typ $\mathrm{e}=$ pdf.

Mathis, Robert. L \&Jackson John. H. (2001). Manajemen Sumber Daya Manusia, Jakarta: Salemba Empat.

McMillan, J.H. and Schumacher, S. (2001). Research in Education. New York: Longman, Inc.

Muchlas. (2005). Perilaku Organisasi. Yogyakarta: Gajah Mada University Press.

Mulyasa, E. (2007). Menjadi Guru Profesional Menciptakan Pembelajaran Kreatif dan Menyenangkan. Bandung: Remaja Rosdakarya.

Pratisto, A. (2009), Statistik Menjadi Mudah Dengan SPSS 17. Jakarta: Elex. Media. Computindo. 
Purwanto, Ngalim. (2011). Psikologi Pendidikan. Bandung: PT Remaja Rosdakarya Bandung.

Robbins SP, dan Judge, (2007). Perilaku Organisasi, Jakarta: Salemba Empat.

Rooijakkers, Ad. (1991). Mengajar Dengan Sukses: Petunjuk Untuk Merencanakan dan Menyampaikan Pengajaran. Jakarta: Presindo.

Rustaman, N. (2001). Ilmu dan Aplikasi Pendidikan. Bandung: Imperial Bhakti Utama Ryan and Deci, (2000). "Intrinsic and Extrinsic Motivations: Classic Definitions and New Directions". Contemporary Educational Psychology 25. page 54-67. http://mmrg.pbworks.com/f/Ryan,+D eci+oo.pdf.

Santoso Singgih, (2002). Statistik Parametrik, Cetakan Ketiga, Jakarta: PT Gramedia Pustaka Utama.

Saroni, Muhammad. (2006). Manajemen Sekolah: Kiat Menjadi Pendidik yang Kompeten. Yogyakarta: Ar-Ruzz Media.

Shahril @ Charil Marzuki (1997). Kajian Sekolah Berkesan Di Malaysia: Model Lima Faktor. Fakulti Pendidikan, Malaysia: Universiti Kebangsaan Malaysia.

Sidi, Indra Djati. (2005). Menuju Masyarakat Belajar. Jakarta: Paramadina

Singarimbun, Masri dan Sofian Effendi. (1989). Metode Penelitian Survey. Jakarta: LP3ES.

Siswanto. (2008). Manajemen Tenaga Kerja Indonesia Pendekatan Administratif dan Operasional. Jakarta: Bumi Aksara.

Slameto. (2003). Belajar dan Faktor-faktor yang Mempengaruhinya. Rineka Cipta. Jakarta.

Sudjana. D (2000). Metode dan Teknik Pembelajaran Partisipatif. Bandung: Falah Production.

Sugiarto dkk. (2003). Teknik Sampling. Jakarta: Gramedia Pustaka Utama.

Sugiyono. (1998). Statistik untuk Penelitian. Bandung: Alfabeta.

Supriyadi.D. (1999). Mengangkat Citra dan Martabat Guru. Yogyakarta: Adicita Karya Nusa.

Syaiful Bahri Djamarah, (2010). Guru dan Anak Didik, Jakarta: Rineka Cipta

Triatna, C. (2008). Perilaku Organisasi Dalam Pendidikan.Bandung: Remaja Rosdakarya.

Undang-undang RI nomor 20 Tahun 2003 Tentang Sistem Pendidikan Nasional.

Uno, Hamzah B. (2008). Teori Motivasi dan Pengukurannya: Analisis di Bidang Pendidikan. Jakarta: Bumi Aksara.

Uno, Hamzah, B. (2011). Teori Motivasi. Jakarta: Bumi Aksara. 
Wahjosumidjo. (2001). Kepemimpinan Kepala Sekolah. Jakarta: Rajagrafindo Persada. Winkel,W.S. (1991). Bimbingan dan Konseling Di Sekolah Menengah (cetakan VII). Jakarta: Grasindo.

Wursanto, Ig. (2006). Manajemen Kepegawaian 1. Yogyakarta: Kanisius. 